\title{
Assessment of Hygiene Practices and Identification of Critical Control Points Relating to the Production of Skewered Meat Sold in N'Djamena-Chad
}

\author{
Abdelsalam Tidjani ${ }^{1,3}$, Abdelsalam Adoum Doutoum², Brahim Boy Otchom ${ }^{1}$, Mahamat Bechir ${ }^{3}$, Hourra \\ Djiguidé Chemi ${ }^{4}$, Fatiou Toukourou ${ }^{5}$ \& Comlan Aristide de Souza ${ }^{6}$ \\ ${ }^{1}$ Faculty of Human Health (FSSH), University of N'Djamena, Chad \\ ${ }^{2}$ University Institute of Sciences and Techniques of Abeche (IUSTA), Chad \\ ${ }^{3}$ National Center of Nutrition and Food Technology (CNNTA), Ministry of Public Health, Chad \\ ${ }^{4}$ Higher Technical School of Agricultural and Forestry (ESTAF), Chad \\ ${ }^{5}$ Laboratory of Microbiology and Food Technology (LAMITA), University of Abomey Calavi, Benin \\ ${ }^{6}$ Laboratory of Microbiology and Quality Control of Foodstuffs, High School of Biological and Food \\ Techniques (ESTBA), University of Lome, Togo \\ Correspondence: Abdelsalam Tidjani, Faculty of Human Health (FSSH), B.P 1117, University of N'Djamena, \\ Chad. E-mail: abdelti@yahoo.fr
}

Received: July 22, 2013 Accepted: September 10, 2013 Online Published: September 20, 2013

doi:10.5539/jfr.v2n5p190 URL: http://dx.doi.org/10.5539/jfr.v2n5p190

\begin{abstract}
Meat is a food of choice because of its nutritional quality. Grills are regularly consumed in Africa and particularly in the Sahelian countries. These are very popular consumer products. However, they can be contaminated by various microorganisms and cause food poisoning if the meat is not handled in hygienic conditions. In order to contribute to improving the quality of these products, we have followed the steps in production of meat skewers by the method of " $5 \mathrm{M}$ " of Ishikawa. The "HACCP decision tree" model was used to determine the Critical Control Points (CCP). Hazard Analysis Critical Control Point (HACCP) is a method and principles of management of food safety. The results of monitoring procedures for making meat skewers showed many shortcomings in hygiene. Six (06) critical points were determined. As for testing, we conducted microbiological analyzes on fifty (50) units of samples corresponding to ten (10) different types of products collected at different stages of production. Compared to AFNOR (French Association of Standardization), criteria for cooked and dehydrated soups and considering the analytical variability associated with the methods of analysis, our results indicate that the products contaminated with germs indicating failure to comply with hygiene. Samples analyzed presented at different stages of production compliance rate of $40 \%$ for total bacteria $\left(30{ }^{\circ} \mathrm{C}\right), 30 \%$ for total coliforms and thermotolerant coliforms $\left(44{ }^{\circ} \mathrm{C}\right)$. The rate of non-compliance is $40 \%$ compared with sulphite-reducing anaerobes. Molds identified in meat skewered and ingredients are Aspergillus niger, Aspergillus flavus, Penicillium sp and Geotrichum sp. Salmonella, S. aureus and yeasts are absent in the samples. Training on good hygiene practices is required at vendors in order to ensure the hygienic quality of grilled meats.
\end{abstract}

Keywords: meat, grilling, skewers, hygienic quality, HACCP, Chad

\section{Introduction}

The consumption of beef like other livestock or hunting animals in the world is very important (Chatellier et al., 2003). The meat is the main source of protein. Beef is also an important source of essential nutrients including high quality protein, iron, zinc and B vitamins. However, because of its nutritional value, meat is a favorable substrate for the development of proteolytic microorganisms (Guiraud \& Galzy, 1980). Meat was traditionally considered responsible for a significant number of foodborne illnesses occurring in humans. Continuation of the problem has been amply demonstrated in recent years by monitoring studies on humans for agents in meat, such as Escherichia coli O157: H7, Salmonella spp, Campylobacter spp. and Yersinia (FAO/WHO, 2004). According to the WHO, more than four (4) billion episodes of diarrhea occur each year worldwide, mostly in developing 
countries. Epidemiological data in hospital showed a prevalence of $19 \%$ of the global disease and bacterial and viral diarrhea were estimated at $20-70 \%$ of cases (WHO, 2004). Diseases such as brucellosis caused by Brucella, tuberculosis caused by Mycobacterium, coal by Bacillus anthracis can be transmitted through undercooked meat. Taenia saginata may be provided by beef (Guiraud \& Galzy, 1980). Meat may be contaminated by the dirty hands of manipulators, soils, polluted water, an unhealthy environment harboring flies and other insects (Barro et al., 2007). In most of Asia, Africa and Latin American cities, a growing number of people use for their daily food, street food, defined as Ready to Eat Foods (RTE), prepared and sold by street vendors or fixed on the street or in public places (FAO, 1988). Street foods provide about $80 \%$ of the urban population (Students, workers, unemployed, street children and traders etc.) to eat outside the home easily and low cost (Dawson, 1991). In Africa, as elsewhere, the food security in terms of health remains precarious. This situation is largely attributable to the street food including meat. This sector (street food) has many shortcomings including the anarchic occupations and unsafe places for the preparation and sale, but also and especially the problem of the sanitary quality of foods due to the non compliance or ignorance of the rules of hygiene in the preparation and sale of food (Yasmeen, 2001; Barro et al., 2002). Several studies have shown that the area of street food is growing in major and secondary cities, while the products offered are not always of good quality (Umoh \& Odoba, 1999). In Chad, major part of the population dinner and lunch in street food shops. Meat is among the most popular street food. But Meat Hygiene is a challenging science with different types of risk (FAO, 2006). Also, food elaborated with satisfactory hygienic standards is one of the essential conditions for promoting and preserving health, and inadequate control is one of the factors responsible for the occurrence of foodborne disease outbreaks (Oliveira et al., 2003). Foodborne disease is caused mainly by the oral ingestion of viable microorganisms (infection) or of the toxins they produce (intoxication) in sufficient amounts to develop pathology (Souza et al., 2004).The objective of this study is to investigate on hygiene practices in order to determine the causes of contamination of meat skewers. The study also proposes to determine the CCP and bring corrective measures to improve the quality of meat skewers consumed in Chad. The results of this work could be a useful tool for information and awareness on good hygiene practices for healthy food production sold on public roads.

\section{Methods}

This is a descriptive study and investigation on hygiene practices in a small establishment of production of meat skewers. The establishment is located in the $5^{\text {th }}$ district of the city of N'Djamena, capital of Chad. The choice of this establishment was made on this site due to regular customers looking cooked skewers. The establishment is the most popular in the city of N'Djamena. The Monitoring procedures by the principles of " $5 \mathrm{M}$ " of Ishikawa allowed to record information about characteristic of staff and hygiene practices in the establishment. The model "decision tree" of the HACCP system (FAO, 2006; Quittet \& Nelis, 1999) was used to determine the CCP. It's a point, step, or procedure at which a significant hazard occurs in food preparation and handling, and at which control can be applied to prevent, eliminate, or reduce the hazard to an acceptable level (FAO, 1993). To get an idea of the bacterial flora contaminating products, a total of fifty (50) units of samples were collected. Its five (05) units of samples corresponding to ten (10) different types of products (fresh meat, raw skewer, raw skewers soaked in water, raw skewers with ingredients, skewered cooked, powder of ingredients etc.) at the production steps of skewers. The samples of fresh meat (beef fillet in the first stage of production) units were collected using gloves, a knife and a sterile clamp and sampling held in different levels (the center and ends of the mass of meat). The same aseptic conditions were used for sample of skewers. Sample units of ingredient powders were obtained by the method of cone (quartering method). Samples are made in the required sampling conditions, then the samples packed in sterilized aluminum paper and then introduced into a cooler and transported to the laboratory. Microbiological analyzes were conducted at the Laboratory of Veterinary and Animal Research (LRVZ) Farcha and Laboratory of Microbiology and Quality Control of Foodstuffs of the High School of Biological and Food Techniques (ESTBA) at the University of Lome-Togo. Microbiological analyzes were performed according to the standard of the French Association of Standardization (AFNOR). Also supports methods for these standards are used (AFNOR, 2002). Searched germs are total mesophilic flora (Total bacteria) $\left(30{ }^{\circ} \mathrm{C}\right)$ (NF.V08-051), Total coliforms $30{ }^{\circ} \mathrm{C}$ (NF.V08-050), Thermotolerant coliforms and E. coli (NF ISO 4831), Anaerobic Sulfite-reducing $44{ }^{\circ} \mathrm{C}$ (NF.V08-061), S. aureus $37^{\circ} \mathrm{C}$ (NF ISO 6888-1) and salmonella (AFNOR.V08-052). Also, molds and yeasts (ISO 21527) were the subject of research. Sample were performed then, after grinding with a moulinex Blender ${ }^{\circledR}$ type $1500 \mathrm{rev} / \mathrm{min}, 10 \mathrm{~g}$ of each homogenate were suspended in $90 \mathrm{ml}$ of tryptone-salt solution containing $0.03 \mathrm{~g} / \mathrm{l}$ of tween 80 and then the regeneration is made for $45 \mathrm{~min}$ at room temperature. For the detection of salmonella, $25 \mathrm{~g}$ of sample of meat and ingredients are homogenized in $225 \mathrm{ml}$ of Buffered Peptone Water (BPW). The count after count taking into account the dilution factor is expressed in Colony Forming Units (CFU)/g. After counting germs, mould colonies form have been isolated in pure culture by subculturing on agar OGA (Oxytetracycline Glucose Agar) and PDA (Potato Glucose Agar) for 
2-6 days of incubation at $30{ }^{\circ} \mathrm{C}$ and $25{ }^{\circ} \mathrm{C}$. After culture, moulds were identified in relation to their cultural characteristics, morphological observation by optical microscopy using the lactophenol cotton blue dye (Guiraud \& Galzy, 1980). The interpretation of the results is made according to the analytical criteria of AFNOR taking into account the analytical variability associated with the methods of analysis. Data on staff characteristics were analyzed using Excel software. Statistical analysis was performed using the chi-square test $\left(\chi^{2}\right)$ for comparison of two variables. Differences were considered significant when $\mathrm{P} \leq 0.05$.

\section{Results}

\subsection{Monitoring the steps for the production of meat skewers}

The boneless beef meat is used for making skewers. Using a knife, the meat is cleaned of film, set nets and then cut into pieces, small pieces of meat are placed in string. Skewer thus obtained is then sprinkled with a mixture of ingredients (ginger, pepper, salt and in large part groundnut cake). Then producers pressed the flat with hand on the tray or the table. It is watered from time to time in peanut oil. The weight of a skewer is about 20 grams. The cooking is done on a circular grill supported by brick: the light located approximately one meter from the grill. In other respects, the cooking is done on a grill with metal stand; fire is 10 or $15 \mathrm{~cm}$ from the grill. Skewers are then placed one by one on the grill. The fire is lit from another source of fire. During cooking, the skewers are sprayed with oil. Toasting time is estimated at 10-15 minutes and sometimes more depending on the number of skewers and fire intensity. At the end, we get cooked are tender, good, smell, yellowish to reddish color and taste. The finished products are then stored on the edge of the grill on a platter. At the request of the customer, they are served on a plate or wrapped in paper. Thus, monitoring of manufacturing steps of meat skewers has established. As shown in Tables 1 and 2, the study identified personal characteristics and hygiene of practices within the establishment. Diagram of production is shown in Figure 1. Figure 2 shows the improved diagram of meat skewers.

Table 1. Staff characteristics

\begin{tabular}{|c|c|}
\hline STAFF & Proportionality $(\%) n=32$ \\
\hline \multicolumn{2}{|l|}{ SEX } \\
\hline Male $(n=32)$ & 100 \\
\hline \multicolumn{2}{|l|}{ AGE } \\
\hline Middle age (year) & 29,48 years old \\
\hline \multicolumn{2}{|l|}{ Level of education } \\
\hline Illiterate $(n=21)$ & 65,62 \\
\hline Primary level $(n=08)$ & 25 \\
\hline Secondary level $(\mathrm{n}=03)$ & 09,37 \\
\hline University & None \\
\hline Other training in good hygiene and good manufacturing practices & None \\
\hline \multicolumn{2}{|l|}{ MEDICAL EXAMINATION } \\
\hline Regular medical examination $(\mathrm{n}=12)$ & 37,5 \\
\hline Irregular medical examination $(\mathrm{n}=20)$ & 62,5 \\
\hline
\end{tabular}

As shown in Table 1, the property is consists exclusively of males with an average age of 29.48 years. Most of the staff is illiterate and does not undergo medical examinations. 


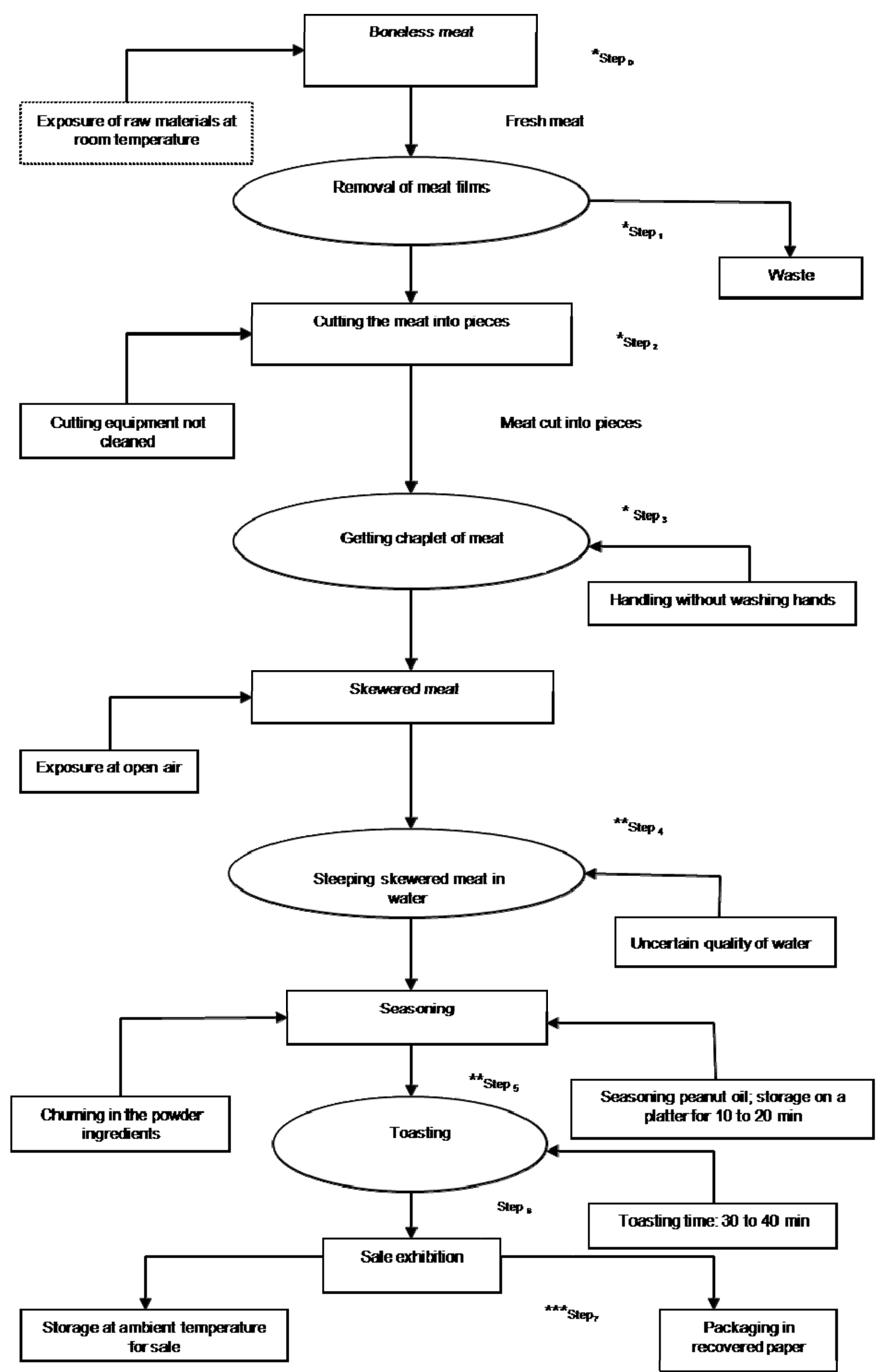

Figure 1. Process flow diagram of meat (beef) skewers

$*=$ Intake germs; $* *=$ Proliferation of germs $* * *=$ Recontamination of the finished product 


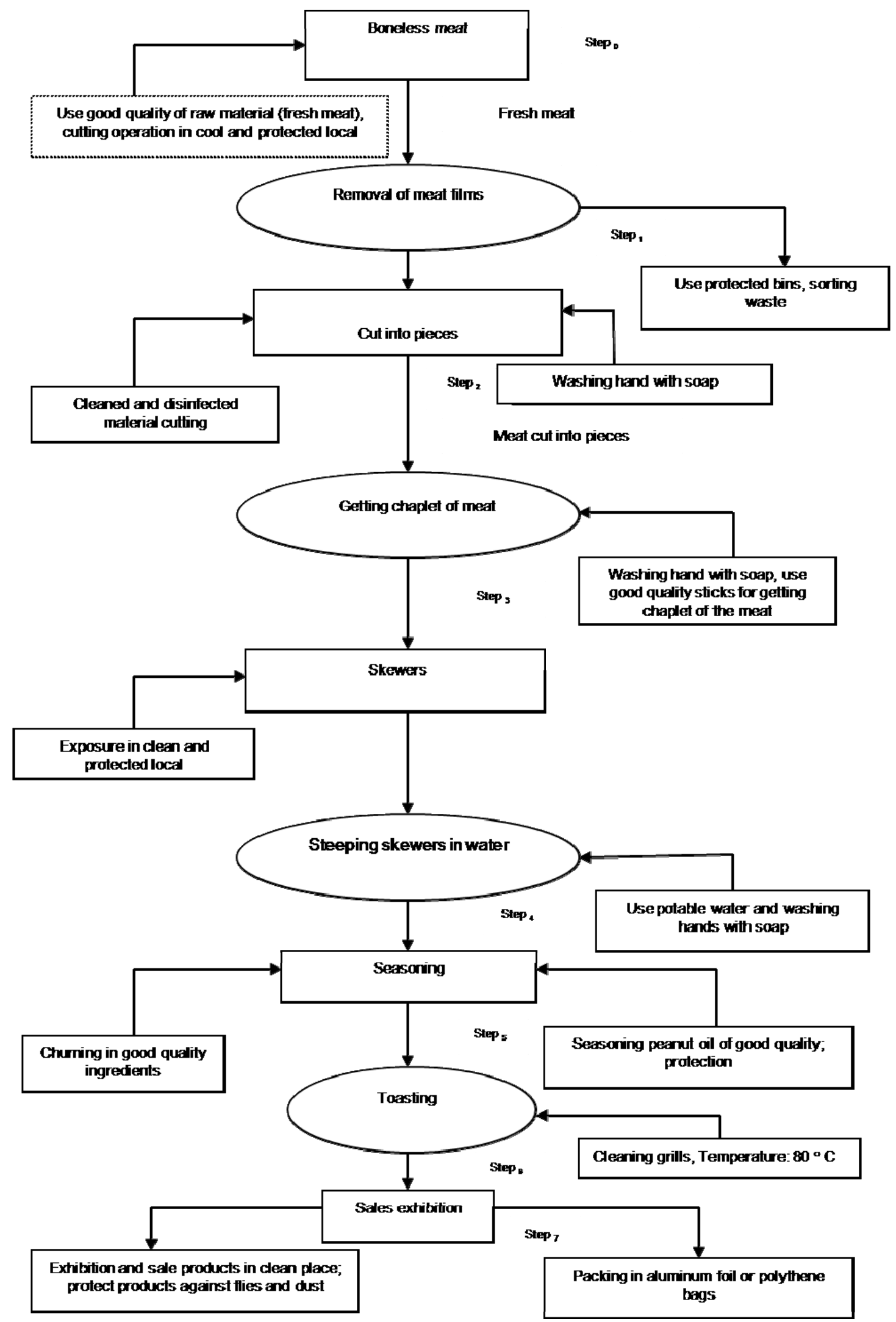

Figure 2. Improved flow diagram of meat (beef) skewers 
Table 2. Evaluation of hygienic practices

\begin{tabular}{|c|c|}
\hline CONTROL POINTS & Appreciation \\
\hline \multicolumn{2}{|l|}{ HYGIENE OF STAFF } \\
\hline Wearing blouse/Apron & + \\
\hline Hair protection & - \\
\hline Cleanliness of clothes & + \\
\hline Hand washing & + \\
\hline Regular medical monitoring & - \\
\hline Knowledge of good hygiene practices, HACCP plan & - \\
\hline \multicolumn{2}{|l|}{ SALES ENVIRONMENT } \\
\hline $\begin{array}{l}\text { General conception (separation of dirty / clean areas, walking forward, presence of flies } \\
\text { and insects) }\end{array}$ & - \\
\hline Environment and surroundings (accessibility, cleanliness, garbage storage) & + \\
\hline State of the surfaces (integrity and cleanliness of floors, walls, doors) & + \\
\hline $\begin{array}{l}\text { Air systems (air quality and ventilation, risk of introducing dust, flies, other insects or } \\
\text { spiders) }\end{array}$ & - \\
\hline $\begin{array}{l}\text { Water points (number, effective operation, clear separation of various non-potable water } \\
\text { circuits ) }\end{array}$ & - \\
\hline Waste water (slopes, presence of areas of stagnation) & + \\
\hline Cloakroom and toilets & - \\
\hline \multicolumn{2}{|l|}{ UTENSILS AND OTHER MATERIALS } \\
\hline State sales tables & ++ \\
\hline State of the furnace & + \\
\hline State of knives and spoons & + \\
\hline Control systems (thermometers, ...) & - \\
\hline Transport food (trucks and containers) & - \\
\hline Waste containers (containers, garbage bags) & + \\
\hline \multicolumn{2}{|l|}{ OPERATION METHODS } \\
\hline Hygienic handling of food & + \\
\hline $\begin{array}{l}\text { Waste and by-products (storage conditions, separation of raw materials and finished } \\
\text { products, ...) }\end{array}$ & - \\
\hline $\begin{array}{l}\text { Compliance with the procedure of cleaning and disinfection (before, during and after } \\
\text { the workday) }\end{array}$ & + \\
\hline $\begin{array}{l}\text { Compliance with the procedure of cleaning and disinfection (before, during and after } \\
\text { the workday) }\end{array}$ & + \\
\hline \multicolumn{2}{|l|}{ RAW MATERIALS } \\
\hline $\begin{array}{l}\text { Quality and traceability of raw materials and ingredients (appearance, compliance, } \\
\text { packaging, certificates of origin, storage, ...) }\end{array}$ & + \\
\hline \multicolumn{2}{|l|}{$\begin{array}{l}\text { Containers and packaging (storage conditions, contact with other materials or } \\
\text { products, ...) }\end{array}$} \\
\hline $\begin{array}{l}\text { Finished products (conformity, packaging, labeling, health brands, storage } \\
\text { conditions, ...) }\end{array}$ & + \\
\hline Management of by-products and waste (circuits, final destination, local treatment) & - \\
\hline Water dishes & + \\
\hline
\end{tabular}

- = improper ; + = little consistent; ++ = consistent.

Table 2 shows the evaluation of hygiene practices taking into account the method of Ishikawa.

\subsection{Microbiological Analysis}

Microbiological analysis shows the presence of aerobic mesophilic bacteria $\left(30^{\circ} \mathrm{C}\right)$ with extreme values between 
$0.09 \times 10^{5}$ and $304.4 \times 10^{5} \mathrm{CFU} / \mathrm{g}$ for an average of $80.18 \times 10^{5} \mathrm{CFU} / \mathrm{g}$. The average germ is $175.02 \times 10^{3} \mathrm{CFU} / \mathrm{g}$ for extreme values 0 to $0.25 \times 10^{3} \mathrm{CFU} / \mathrm{g}$ corresponding to total coliform. For thermotolerant coliforms $\left(44{ }^{\circ} \mathrm{C}\right)$, the values range from 0 to $250000 \mathrm{CFU} / \mathrm{g}$ with an average of $102713 \mathrm{CFU} / \mathrm{g}$. Counting Sulfito-reducing anaerobes gives values between 0 and $960 \mathrm{CFU} / \mathrm{g}$ with an average value of $180 \mathrm{CFU} / \mathrm{g}$. The number of germs varies from 0 to $5.5 \times 10^{2} \mathrm{CFU} / \mathrm{g}$ with an average of $0.74 \times 10^{2} \mathrm{CFU} / \mathrm{g}$ for moulds. S. aureus, Salmonella sp and yeasts are absent in products. Test results and compliance rates are indicated in Tables 3 and Table 4.

Table 3. Assessment of samples at different steps of production of meat skewers

\begin{tabular}{cccccc}
\hline & & \multicolumn{4}{c}{ NUMBER OF GERMS CFU/g } \\
\cline { 3 - 6 } types & $\begin{array}{c}\text { Total germs } \\
\left(30{ }^{\circ} \mathrm{C}\right)\end{array}$ & $\begin{array}{c}\text { Total } \\
\text { coliform }\end{array}$ & $\begin{array}{c}\text { Coliform } \\
\text { thermotolerant } \\
\left(44^{\circ} \mathrm{C}\right)\end{array}$ & $\begin{array}{c}\text { Sulfito- } \\
\text { reducing } \\
\text { anaerobes }\end{array}$ & Moulds \\
\hline $\begin{array}{c}\text { Fresh meat } \\
\text { Raw skewer }\end{array}$ & $104.4 \times 10^{5}$ & $250 \times 10^{3}$ & 250000 & 220 & 0 \\
Raw skewers soaked in & $304.4 \times 10^{5}$ & $250 \times 10^{3}$ & 250000 & 960 & 0 \\
water & $42.7 \times 10^{5}$ & $250 \times 10^{3}$ & 250000 & 0 & 0 \\
Skewers of seasoned meat & $150.2 \times 10^{5}$ & $250 \times 10^{3}$ & 250000 & 320 & 0 \\
Skewered cooked & $0.09 \times 10^{5}$ & $0.006 \times 10^{3}$ & 0 & 0 & 0 \\
Cooked skewers cooled & $88 \times 10^{5}$ & 0 & 0 & 300 & 0 \\
Powder of ingredients & $4 \times 10^{5}$ & $250 \times 10^{3}$ & 130 & 0 & $1.94 \times 10^{2}$ \\
Cooked skewers served & $0.09 \times 10^{5}$ & $0.25 \times 10^{3}$ & 6 & 0 & 0 \\
Cooked skewers without & $9 \times 10^{5}$ & $250 \times 10^{3}$ & 25000 & 0 & 0 \\
ingredients & $99 \times 10^{5}$ & $250 \times 10^{3}$ & 2000 & 0 & $5.5 \times 10^{2}$ \\
Skewered cooked stored & & $10 \mathrm{CFU} / \mathrm{g}$ & $30 \mathrm{CFU} / \mathrm{g}$ & $\mathrm{NC}$ \\
AFNOR criteria : & $3 \times 10^{5} \mathrm{CFU} / \mathrm{g}$ & $10^{3} \mathrm{CFU} / \mathrm{g}$ & &
\end{tabular}

Notes: Samples do not contain salmonella, $S$. aureus and yeasts.

Table 4. Conformity of samples

\begin{tabular}{|c|c|c|c|c|c|c|c|c|}
\hline Germs & $\begin{array}{l}\text { Average } \\
\mathrm{n}^{*}=50 \\
\mathrm{CFU} / \mathrm{g}\end{array}$ & $\begin{array}{c}\text { Extrem value } \\
\text { CFU/g }\end{array}$ & $\begin{array}{c}\mathrm{m}^{*} \\
\mathrm{CFU} / \mathrm{g}\end{array}$ & $\begin{array}{c}3 \mathrm{~m}^{*} \\
\mathrm{CFU} / \mathrm{g}\end{array}$ & $10 \mathrm{~m}^{*}$ & $\begin{array}{l}\text { Conformity } \\
\text { Number of } \\
\text { samples } \\
\text { In } \\
\text { accordance }\end{array}$ & $\begin{array}{c}\text { Not in } \\
\text { accordance }\end{array}$ & $\%$ \\
\hline $\begin{array}{l}\text { Total germs } \\
\quad\left(30^{\circ} \mathrm{C}\right)\end{array}$ & $80.18 \times 10^{5}$ & $\begin{array}{c}0.09 \times 10^{5} \\
304.4 \times 10^{5}\end{array}$ & $3 \times 10^{5}$ & $9 \times 10^{5}$ & NA & 4 & 6 & 40 \\
\hline Total coliform & $175.02 \times 10^{3}$ & $\begin{array}{c}0 \\
250 \times 10^{3}\end{array}$ & $10^{3}$ & NA & $10^{4}$ & 3 & 7 & 30 \\
\hline $\begin{array}{l}\text { Coliform } \\
\text { thermotolerant } \\
\qquad\left(44^{\circ} \mathrm{C}\right)\end{array}$ & 102713 & $\begin{array}{c}0 \\
250 \times 10^{3}\end{array}$ & 10 & NS & 100 & 3 & 7 & 30 \\
\hline $\begin{array}{l}\text { Sulfito- reducing } \\
\text { anaerobes }\end{array}$ & 180 & $\begin{array}{c}0 \\
960\end{array}$ & 30 & 90 & NA & 6 & 4 & 60 \\
\hline S. aureus & 0 & 0 & 102 & $3 \times 10^{2}$ & NA & 10 & 0 & 100 \\
\hline Salmonella sp & 0 & 0 & $\mathrm{Abs} / 25$ & NA & NA & 10 & 0 & 100 \\
\hline Mold & $0.74 \times 10^{2}$ & $0-5.5 \times 10^{2}$ & $\mathrm{NC}$ & $\mathrm{NC}$ & $\mathrm{NC}$ & $\mathrm{NC}$ & $\mathrm{NC}$ & $\mathrm{NC}$ \\
\hline
\end{tabular}

$\mathrm{n}^{*}=$ Total number of units of samples; $\mathrm{m}^{*}=$ Standards AFNOR (French Association of Standardization) Acceptability limit related to the method of counting: $3 \mathrm{~m}^{*}=$ Solid medium; $10 \mathrm{~m} *=$ Liquid medium; NA = Not applicable; NC: Not considered. 


\subsection{Determination of Critical Control Points (CCP)}

Using the "decision tree" of the HACCP system, we have identified six (6) critical points on steps. Hazards and causes of hazards have been identified. Risk analysis, critical point and corrective measures are shown in Table 5 .

Table 5. Critical control points and corrective measures

\begin{tabular}{|c|c|c|c|c|c|c|}
\hline $\mathrm{N}^{\circ}$ & Steps & Methods & Dangers & Due to the dangers & $\mathrm{CCP}$ & Remedial action \\
\hline 1 & $\mathrm{E}_{\mathrm{o}}^{*}$ & $\begin{array}{l}\text { Receipt of } \\
\text { meat, } \\
\text { boning }\end{array}$ & $\begin{array}{l}\text { Development of } \\
\text { microbial } \\
\text { contamination } \\
\text { germs, infections, } \\
\text { poisoning }\end{array}$ & $\begin{array}{c}\text { Sick animal; } \\
\text { Defect inspection, out } \\
\text { of the cold chain, } \\
\text { long duration of } \\
\text { transport }\end{array}$ & Yes & $\begin{array}{l}\text { Inspection of the animal and } \\
\text { removal of diseased } \\
\text { animals; use refrigerated } \\
\text { vehicles and supply } \\
\text { containers with traceability; } \\
\text { compliance with GHP ; } \\
\text { quickly transport the meat; } \\
\text { refuse suspect meat }\end{array}$ \\
\hline 2 & $\mathrm{E}_{1}$ & $\begin{array}{l}\text { Removal } \\
\text { of meat } \\
\text { film } \\
\text { (waste) }\end{array}$ & $\begin{array}{c}\text { Microbial } \\
\text { contamination }\end{array}$ & $\begin{array}{l}\text { Non-compliance with } \\
\text { basic hygiene; use of } \\
\text { non-disinfected } \\
\text { cutters; tables and } \\
\text { other equipment not } \\
\text { cleaned }\end{array}$ & No & $\begin{array}{l}\text { Wash hands with soap; } \\
\text { using clean clothes for the } \\
\text { filter }\end{array}$ \\
\hline 3 & $\mathrm{E}_{2}$ & $\begin{array}{l}\text { Cutting the } \\
\text { meat into } \\
\text { pieces }\end{array}$ & $\begin{array}{l}\text { Proliferation of } \\
\text { microbes }\end{array}$ & $\begin{array}{l}\text { Poor control of the } \\
\text { temperature }\end{array}$ & No & $\begin{array}{l}\text { Cut the meat in a clean and } \\
\text { fresh environment }\end{array}$ \\
\hline 4 & $\mathrm{E}_{3}^{*}$ & $\begin{array}{c}\text { Getting } \\
\text { chaplet } \\
\text { pieces of } \\
\text { meat }\end{array}$ & $\begin{array}{l}\text { Proliferation of } \\
\text { microbes }\end{array}$ & $\begin{array}{l}\text { Non-compliance with } \\
\text { basic hygiene; Poor } \\
\text { control of the } \\
\text { torque-time } \\
\text { temperature; }\end{array}$ & Yes & $\begin{array}{l}\text { Wash hands with soap; } \\
\text { Quickly place the pieces of } \\
\text { meat in the pins }\end{array}$ \\
\hline 5 & $\mathrm{E}_{4}^{*}$ & $\begin{array}{l}\text { Steeping } \\
\text { skewers in } \\
\text { water }\end{array}$ & $\begin{array}{l}\text { Microbiological } \\
\text { and } \\
\text { physicochemical } \\
\text { water } \\
\text { contamination }\end{array}$ & $\begin{array}{l}\text { Poor quality of water; } \\
\text { non-renewal of the } \\
\text { water used for } \\
\text { washing utensils }\end{array}$ & Yes & Use potable water; \\
\hline 6 & $\mathrm{E}^{*}$ & Seasoning & $\begin{array}{l}\text { Microbiological } \\
\text { and } \\
\text { physicochemical } \\
\text { contamination }\end{array}$ & $\begin{array}{l}\text { Inappropriate } \\
\text { ingredients and oil; } \\
\text { Poor conservation }\end{array}$ & Yes & $\begin{array}{l}\text { Use a good quality } \\
\text { ingredients and oil; good } \\
\text { conservation }\end{array}$ \\
\hline 7 & $\mathrm{E}_{6}^{*}$ & Toasting & $\begin{array}{l}\text { Microbial and } \\
\text { chemical } \\
\text { contamination }\end{array}$ & $\begin{array}{l}\text { No mastery of the } \\
\text { time-temperature }\end{array}$ & Yes & $\begin{array}{c}\text { Grilling at a temperature of } \\
80^{\circ} \mathrm{C} \text {; use quality wood for } \\
\text { toast }\end{array}$ \\
\hline 8 & $E^{*}{ }_{7}$ & $\begin{array}{l}\text { Storage } \\
\text { and } \\
\text { packaging }\end{array}$ & $\begin{array}{l}\text { Microbiological } \\
\text { and } \\
\text { physicochemical } \\
\text { contamination }\end{array}$ & Improper packaging & Yes & $\begin{array}{c}\text { Choose a good sealed } \\
\text { packaging }\end{array}$ \\
\hline
\end{tabular}

$*=\mathrm{CCP}=$ Critical Control Point

\section{Discussion}

\subsection{Hygiene Practices in the Manufacturing Process of Skewered Meat}

It appears from our study of the deficiencies in hygiene practices at the point of sale and production of skewered meat. The establishment is located on the road. Generally, producers and sellers occupy haphazardly places (anarchic way) to prepare and sell their products. Cutting and toasting of meat do so outdoors. We found that the removal of dirty water is usually in the nearest gutter, in landfills and roadside. Waste management is also a concern. There is no liquid discharge system, which leads to an accumulation of dirty water and garbage that may attract flies and other insects. Studies (Barro et al., 2006; Muinde \& Kuria, 2005) indicate that an unsafe 
place for the preparation and sale of street food, marked by the presence of various solid waste liquid provides a favorable environment for flies and other insects. Other studies (de Jesus et al., 2004; Szalanski et al., 2004) showed that insects play an important role in the transmission of pathogenic microorganisms that cause infections. The flies are especially dangerous because of their feeding mode. They provide the mechanical transmission of germs from one place to another landing on contaminated surfaces (waste or feces) and on the food briefly opened. Large populations of two species of flies have been identified on the websites selling street food: it is the housefly and green fly respectively Musca domestica and Lucilia caesar (Barro et al., 2006). The observations revealed that these two insects flit and are often found in foods. In addition, the analysis showed that these flies carry many different bacteria and thus are vectors. Musca domestica, each time landing on the surface of the food, leaving a large number of pathogenic bacteria (de Jesus et al., 2004) and is recognized as a vector responsible for several diseases in all continents (Allan \& Zurek, 2004). The importance of the fly population on sites of preparation and sale of food indicates the presence or proximity of an unhealthy environment so favorable to the living conditions of these insects (Barro et al., 2006). Microbiological analyzes on feces, legs and snout of two species of fly $M$. domestica and $L$. caesar have highlighted their role as a reservoir of microorganisms. In their diet or their movement on a surface or on food and through their excreta, these flies can deposit several microorganisms (de Jesus et al., 2004. Nichols, 2005). In addition, FAO (2007) reports that pests (mice, roaches, termites, etc.) are a major danger to the safety and suitability of food. Other studies (Yasmeen, 2001) showed that in Africa, food security in terms of health remains precarious. This is largely due to the street food. This area has many shortcomings, including the anarchic occupations and unsafe places of preparation and sale of food.

Compared to raw materials, the meat used in the manufacture of meat skewers comes from the central market of the city of N'Djamena or directly from slaughterhouses. For transportation, the establishment has not an adequate vehicle to transport meat. Refrigerated vehicles are used only to transport meat from the slaughterhouse to market. From the market to establishment, often transporting meat is done by commercial vehicles or rickshaws (holder all). The cold chain is interrupted at this point, which could affect the quality of meat for processing. It has been reported by several authors use of raw materials and low quality ingredients, food additives unauthorized, poor manufacturing practices, preservation, packaging and sales, often in unhealthy environments (Barro et al., 2002). However, FAO (2007) indicates that whatever the mode of supply of raw materials and ingredients, it is important to choose wisely raw materials and ingredients from known trader or to the market with guaranteed safety. According to FAO/WHO (2004), primary production is an important source of risk associated with meat. In many developing countries, the lack of proper slaughter structure and the existence of unsatisfactory conservation techniques can result in enormous losses of meat and its derivatives (FAO, 2006), which could affect the quality of the raw material. Another concern is that of the origin and the level of contamination of these products because of illegal slaughter cases with an unknown over the health of the animals were reported by Barro et al. (2002). Also, the quality of the finished product depends on the quality of the raw material. There is a need for the seller to procure fresh meat of good quality. About the water used in the establishment, we noticed a severe lack of drinking water in the meat processing sites. Producers often use water from different fountains in the city, but the treatment of these waters and especially their distribution is made in very poor hygienic conditions. Use of poor quality water could be the source of contamination and can cause poisoning in consumers. Similar observations were made by other authors (Borchardt et al., 2003; Leclerc et al., 2002; Mamontova et al., 2000). Another study in Calcutta showed that $47 \%$ of water used in street food was contaminated with fecal bacteria (Chakravarty and Canet, 1996). Criteria for quality of drinking water, bacteriological parameters deserve the utmost vigilance because they reflect an immediate risk to the health of the consumer (Kimassoum et al., 2011).

For the equipment, cutting operations are carried out on non-cleaned tables, other equipment and utensils (knives, cleavers, plates etc.) are poorly cleaned and disinfected. Several authors (Pérez- Rodríguez et al., 2007; Vorst et al., 2006) have noted that slicing machines and cutting utensils are recognized as important vehicles of contamination of cooked meat products both at factory and sale points. Meat can become contaminated during storage by contact with toxic substances or absorption of toxic metals.

The study also revealed shortcomings in the working methods and staff attitude. Most of the staff $(65.62 \%)$ is not educated. The difference between literate and illiterate is not significant $\left(\mathrm{x}^{2}=3.5, \mathrm{ddl}=1, \mathrm{p} \geq 0.10\right)$. However, rarely the staff wears blouses and aprons; uses dirty and worn clothes and often do not wash their hands before starting work. But disease prevention is through good practices, including hand washing with soap. The importance of providing theoretical and practical training at all levels of the food chain, including food handlers and consumers has been highlighted by several authors (Abdelrahim et al., 2012; FAO, 2007; Barro et al., 2007). 
The hands of food handlers are an important means of cross-contamination (Allwood et al., 2004). Poor personal hygiene of food vendors frequently contributes to outbreaks of foodborne diseases caused by microorganisms such as Staphylococcus aureus and Gram-negative bacilli such as Salmonella sp (Hundy \& Cameron 2002). We noticed that sellers handle at the same time money and the cooked skewers. The handling of finished products and money by the same time probably can potentially causes cross-contamination. These improper practices have been identified as major contamination factor in this study and those of several other authors (Tidjani et al., 2013; Abelrahim et al., 2012; King et al., 2000). Inappropriate hand washing practices in handlers at a hospital school in India was observed too by Malhotra et al. (2006). In addition, Mosupye et al. (2000), Bhaskar et al. (2004) found that in street food, especially among sellers of grilled meat, knives are used for cutting raw and cooked meat without cleaning between these two uses, a practice that promotes germ contamination carried by raw foods (cross contamination). Furthermore, this study shows a significant difference $\left(\mathrm{x}^{2}=4.5, \mathrm{ddl}=1, \mathrm{p} \geq\right.$ $0.02)$ between the staff regularly conducts medical visits $(37.5 \%)$ and those who do not $(62.5 \%)$. In developing countries, more than $60 \%$ of food-related diseases are caused by microbiological agents, underscoring that food preparers are the main vehicles of this transmission (Panza \& Sponholz, 2008). In their study, A.K.C. Campos et al. (2009) observed the absence of periodical health examination in 51.9\%. According to Codex Alimentarius (2003), the persons, who are known or suspected of having any disease might be transmitted by food, are forbidden to handle food items. Also, Idowu and Rowland (2007) in their study, found the presence of fecal-oral transmission parasites in the handlers studied and they emphasize the importance of periodical health examinations to diminish the risk of food contamination.

\subsection{Microbiological Analysis}

Of all the products analyzed, $40 \%$ are consistent with respect to aerobic mesophilic bacteria $\left(30{ }^{\circ} \mathrm{C}\right), 30 \%$ compared to total coliforms and $30 \%$ compared to thermotolerant coliforms $\left(44{ }^{\circ} \mathrm{C}\right)$. Regarding the Sulfito-reducing anaerobes, $60 \%$ of the samples are consistent. Molds are present with an average of $0.74 \times 10^{2}$ $\mathrm{CFU} / \mathrm{g}$; it is Aspergillus niger in the sample skewer cooked retained by the seller and Aspergillus flavus, Penicillium $s p$ and Geotrichum $s p$ in the sample of ingredients.

It is clear from our analysis that the fresh meat is highly contaminated by germs indicating breaches of hygiene, the contaminations was due to the rupture of the cold chain during the transportation of the product to the place of production but also to cutting operations that are usually outdoors. According to Bourgeois \& Leveau (1991), cutting operations meat may carry microorganisms from the environment (germs soil, air) or staff. Other studies (Barro et al., 2002) on the microbiological quality of staple foods have shown that products such as meat may be contaminated because of their exposures for hours at room temperature.

The number of germs increases considerably in the sample of raw skewer. This is due to the fact that the meat pieces are pressed into the pins by hand and the skewer is then deposited on a table littered with flies. This step is critical because the basic hygiene rules are far from being met due to the low level of education vendors and lack of training on Good Hygiene Practices (GHP) account and Good Manufacturing Practices (GMP). Several studies have shown that health precautions for handling street foods vary and have been identified as a major factor of contamination (Barro et al., 2002; King et al., 2000). However, the number of germs decreases after steeping in water: washing with water could be the cause of this decline. But the product can be contaminated again due to the quality of the washing water.

In the sample of spicy raw skewer, the number of germs increases, this contamination comes from the exposure of the product to air but also from spices and ingredients. Powders ingredients are composed mainly of groundnut cake. Peanut is a favorite place of Aspergillus flavus that in areas where this legume is grown ecological and climatic conditions are met ideal for the development of this slime. Studies have shown that the vast majority of these flavoring ingredients may be contaminated by microorganisms (Garrido et al., 1992) producing toxins harmful to consumer health. Among the toxigenic microorganisms, mycoflora occupies a significant place, they are all of the genus Aspergillus; three of them are involved: A. flavus, A. parasiticus and $A$. nomius, but it is unknown in the contamination of plant foods (Wilson \& Payne, 1994). Studies performed on powders dried meat seasoning ingredients showed various species of fungi namely A. flavus, A. Niger, Geotrichum sp. and Rhizopus sp. Studies of dosage of aflatoxins in the ingredients used for seasoning dried meats showed in some samples the presence of aflatoxins (Tidjani et al., 2008). Baracco et al. (1982) observed that spices are a favorable substrate swarm of various microorganisms because they are not always collected in very good conditions: they are frequently contaminated by land, most often dried by hand, subject to weather conditions and their fermentation is not always desirable. Several species identified are spore forming bacteria resistant to heat (bacilli, Clostridium perfringens etc.), and often moulds responsible for defect in appearance. Pepper shows generally the most contaminated. 
After cooking, there is a decrease in the number of total germs $\left(0.09 \times 10^{5} \mathrm{CFU} / \mathrm{g}\right)$, but the germs are not eliminated because the grill is remote from the fire, resulting in a lack of cooking. The number of germs increases again in the sample cooled cooked skewers and this is due to the fact that the skewers are exposed to the open air for sale at the moment and could have at this time secondary contamination. This step is also critical. The sample of raw skewers with ingredients showed high values of the order of $250 \times 10^{3} \mathrm{CFU} / \mathrm{g}$ higher than the threshold of acceptability in relation to total coliforms and thermotolerant coliforms $\left(44^{\circ} \mathrm{C}\right)$. Skewer cooked, retained and reheated presented values $99 \times 10^{5} \mathrm{CFU} / \mathrm{g}$ for total bacteria, $250 \times 10^{3} \mathrm{CFU} / \mathrm{g}$ for total coliforms and $2000 \mathrm{CFU} / \mathrm{g}$ for thermotolerant coliforms $\left(44{ }^{\circ} \mathrm{C}\right)$, these values are above the threshold acceptability. Only the sample skewer cooked complies against all searched germs. Other studies (Bryan et al., 1992) reported that cooking and food exposure at room temperature are two important critical points at street food. Then cooked skewers are arranged on trays for sale. In most cases, they are not covered and are exposed to the open air and then sold without further heating. However, in a few outlets, the products are displayed in glass cases. Unfortunately many foods sold on the street are not covered (Barro et al., 2002). The skewers are served on plates washed in dirty water or sometimes on paper (for example packaging of cement recovered, newspapers etc.). About packaging, his role is to protect the contents against all attacks and contamination can affect the quality of the food, it should be sealed, suitable and cover all the food. Food packaging today is a major issue for both food businesses and companies producing plastic packaging (Mellouet et al., 2009). Food packaging are considered to be one of the causes of food contamination, they contain many low molecular weight additives in their formulation and consequently present a risk of interaction with food that they contain by releasing in this part of their additives or processing aids. The study of food contamination by packaging has been highlighted by others researchers (Petersen \& Beindhal, 2000).

\subsection{Identification of Critical Control Points}

The foods that we eat are mostly of biological origin (plant or animal). Changes to this food, whether enzymatic or microbiological origin, make them quickly inedible or unfit for consumption (Clinquart, 2005). To control the quality of our food from farm to fork, approaches such as HACCP is essential. HACCP is internationally recognized as the best method to ensure the safety of a product (Montarjemi \& Kaferstein, 1999). The control of hazards threatening the hygienic nature of food safety requires the adoption of this system (Rozier, 1996). We were able to identify on the production of meat skewers six (6) critical points concerning the steps of reception of the raw material, getting chaplet pieces of meat, steeping skewers in water, seasoning with ingredients and oil, toasting and packing. Also studies (Tidjani et al., 2013; John et al., 2001) have identified the critical points in the food preparation (complementary food and cheese). However, other studies (Pérez-Rodríguez et al., 2010) confirmed that Small and medium-sized establishments are associated with worse hygiene practices compared to Large Sized establishments. John et al. (2001) observed that the purchasing Ready-To-Use Foods and ingredients from market vendors poses a considerable health risk. The reasons for this are apparent from observational data on hygiene practices in the market. Foods and ingredients are often displayed openly on tables and on the ground in very poor sanitary environments.

According to Drabo et al. (2009), street food is both a source of revenue as an indicator of the reorganization of the domestic structure and dietary practices. It is therefore important to produce quality to protect the health of consumers, but also increase the efficiency of business. In view of these shortcomings and in accordance with procedures HACCP (Hazard Analysis and Critical Control Point), this study has developed an improved process flow diagram of meat skewers of meat (Figure 2) and propose corrective measures (Table 5) to improve the quality of meat skewers very popular with consumers. Also, at the end of this study, we had recommended to the producers, sellers and consumers to source raw materials of good quality; to control temperatures for cooking, cooling, storage and distribution; to have potable water at all times during working hours; to have an efficient effluent disposal and waste system; to clean and disinfect knives, steels, cleavers, saws and other instruments; to ensure a permanent training methods of hygienic handling of food: wash your hands often and thoroughly with a product suitable for cleaning the hands and use hot water ; to promote personal hygiene by medical visits and health education activities; to monitor the cooking; and to avoid cross-contamination.

\section{Conclusion}

This study has allowed us to appreciate the quality of meat skewers from the receipt of fresh meat until the end through the steps of cutting the meat into pieces, their seasoning and toasting etc. Tracking processing techniques enlightened us on the general hygiene conditions for making skewers. In retail butchers, producers and sellers, personal hygiene and clothing are not obvious (clothing and dirty, smock, non-existent or inadequate hand washing, dilapidated equipment often not remediated etc.). At different stages of production of skewers, there is a lack of personal hygiene and dress, the activity is outdoors and the finished products are exposed to the open 
air, so that the cooked skewers cooled can be contaminated again with germs. Often the persons who serve skewers to customers are also those who collect money, it can be a support vehicle germ. Compared to the microbiology analysis, the products are much more contaminated by indicator germs breach of the rules of hygiene as by moulds. However, the samples analyzed did not contain salmonella, S. aureus and yeasts.

For the first time, this study has allowed us to exchange on the concept of HACCP with the producers of the skewers. Based on this system, the dangers and causes of hazards have been identified, six (06) critical points were determined and corrective actions have been implemented. Also, an approach for meat hygiene based on risk analysis requires that steps be taken at the point of the food chain where they can most contribute to reducing food-borne risks to consumers. This should happen through the prevention and control of cases of contamination of the raw material and in the processing steps of the meat skewers. Moreover, it is necessary to apply the principles of Hazard Analysis and Critical Control Point (HACCP) in all stages of production to mastering the critical points and protect the health of consumers. To avoid infections and food poisoning, precautions for hygiene practices including sanitation of raw materials, personnel and the environment should be taken to improve the quality of meat skewers and protect the health of consumers. Also training on Good Hygiene Practices (GHP) is required at vendors to ensure the hygienic quality of grilled meats. It's also important to develop Guides to Good Hygiene Practices (GGHP) for forming producers, sellers and consumers.

\section{References}

Abdelrahim, A. M., Tidjani, A., Doutoum, A. A., Barro, N., \& Traore, A. S. (2012). Evaluation of the microbiological quality of braised fish and their seasonings sold in the streets of Ouagadougou (Burkina Faso). Microbiol. Hyg. Alim, 24(69), 47-54.

AFNOR. (2002). Food microbiology. Horizontal reference methods. Volume 1, 8th St Denis La Plaine, Code standards, Food, p. 299.

Allan, M. J., \& Zurek, L. (2004). Association of Escherichia coli O157:H7 with houseflies on a cattle farm. Appl. West Afr. Food Nutr., 3, 7578-7580. http://dx.doi.org/10.1128/AEM.70.12.7578-7580.2004

Allwood, P. B., Jenkins, T., Paulus, C., Johnson, L., \& Hedberg, W. (2004). Hand washing compliance among retail food establishment workers in Minnesota. J. Food Prot, 67(12), 2825-2828.

Ana, K. C. C., Ângela, M. S. C., Liana, B. G. P., Neide, R. F., Paulo, R. M., \& Tânia, L. M. S. (2009). Assessment of personal hygiene and practices of food handlers in municipal public schools of Natal, Brazil. Food Control, 20, 807-810. http://dx.doi.org/10.1016/j.foodcont.2008.10.010

Baracco, P., Berger, Y., Durant, P., Jean, C. F., Jean, G., Jacques, G., ... Jean, S. (1982). Encyclopedia of charcuterie. S. A. Soussana (Ed.), p. 787. France: Orly.

Barro, N., Gamene, A. A., Itsiembou, Y., Savadogo, A., Nikiema, A. P., Outtara, C. A. T., Traore, A. S. (2007). Street-vended Food improvement: Contamination Mecanism and Application of Food Safety Objective Strategy: Critical review. Pakistan journal of nutrition., 6(1), 1-10.

Barro, N., Savadogo, A., Outtara, C. A. T., \& Traore, A. S. (2006). Carriage bacteria by proboscis, legs and faeces of two flies in street food vending sites in Ouagadougou, Burkina Faso. J. Food. Prot., 69(8), 2007-2010.

Barro, N., Outtara, C. A. T., Nikiema, A. P., Outtara, A. S., \& Traore, S. A. (2002). Evaluation of the microbiological quality of some street food in the city of Ouagadougou in Burkina Faso. Cah. Health, 12, 369-374.

Bhaskar, J., Usman, M., Smitha, S., \& Bhat, G. K. (2004). Bacteriological profile of street foods in Mangalore. Indian J. Med. Microbiol., 22(3), 197.

Borchardt, M. A., Bertz, P. D., Spencer, S. K., \& Battigelli, D. A. (2003). Incidence of enteric viruses in grounwater from haousehol wells in wisconsin. Appl. Environ. Microbiol., 69, 1172-1180. http://dx.doi.org/10.1128/AEM.69.2.1172-1180.2003

Bourgeois, C. M., \& Leveau, J. Y. (1991). Technical analysis and control in the food industry. Microbiological control. Volume 3, (2nd ed). Technical and documentation. p. 454., France: Lavoisier.

Bryan, F. L., Teufel, F., Riaz, S., Roohi, S., Qadar, F., \& Malik, Z. (1992). Hazard and critical control points of street-vending operation in motain resort town in Pakistan. J. Food Prot., 55, 534-541.

Chakravaty, I., \& Canet, C. (1996). Street food in Calcutta. Food. Nutr. Agric., 17(18), 7.

Chatellier, V., Guyomard, K. K., \& Le Bris. (2003). The consumption of beef in the world and in the European 
Union: Evolution. INRA Prod. Anim, 16(5), 381-391.

Clinquart, A. (2005). Les techniques de conservation des aliments. Université de Liège, Faculté de Médecine vétérinaire. Département des Sciences des denrées alimentaires (sect. Technologie). Reteieved from http ://www.dsda.ulg.ac.be

Codex Alimentarius. (2003). Recommended international code of practice general principles of food hygiene. CAC/RCP 1-1969, Rev. 4.

Danwson, R. J., \& Canet, C. (1991). International activities in street food. Food Contr, 2(3), 135-139. http://dx.doi.org/10.1016/0956-7135(91)90081-7

Drabo, K. M., Pare, Toe L, Savadogo, L. G. B., Tarnagda, Z., Zeba, A. N., Zongo, I., Rouamba, J., Toe, A., Ouédraogo, D., \& Ouédraogo, J. B. Caractéristiques de l'alimentation de rue dans la ville de Bobo-Dioulasso, Burkina Faso (2009). Bull Soc Pathol Exot, 102(1), 36-40.

de Jesus, A. J., Olsen, A. R., Bryce, J. R., \& Whiting, R. C. (2004). Quantitative contamination and transfer of Escherichia coli from foods by houseflies, Musca domestica L. (Dipteria: Muscidae). J. Food Microbiol., 93, 259-262. http://dx.doi.org/10.1016/j.ijfoodmicro.2003.12.003

FAO. (2007). The Good Hygiene Practices in the preparation and sale of food street food in Africa. Tool for training. p. 188.

FAO. (2006). Good practices for the meat industry. Manual No. 2, FAO Animal Production and Health. Rome, Italy, Section 10, pp. 3-6.

FAO/WHO. (2004). Mixed / WHO Food Standards Programme FAO. Report of the Tenth Session of the Codex Committee on Meat Hygiene Auckland (New Zealand), p. 85.

FAO. (1993). Guidelines for the application of the hazard analysis critical control point (HACCP) system. Rome, Food and Agricultural Organization, 1993 (Codex Alimentarius Commission).

FAO. (1988). Street foods. Report of a FAO expert consultation, Yogyakarta, Indonesia. Food Nut Paper 1988, 46.

Garrido, D., Jordal, M., \& Pozzo, R. (1992). Mould flora and aflatoxin-producing strains of Aspergillus flavus. Indian J. Mycol. Plant Pathol., 21, 211-212.

Guiraud, J., \& Galzy, P. (1980). The microbiological analysis in the food, food engineering question. Editions of the new plant (p. 239). France: Paris.

Hundy, L., \& Cameron, S. (2002). An outbreak of infections with a new Salmonella phage type linked to a symptomatic food handler. Comm. Dis. Intell., 4, 562-567.

Idowu, O. A., \& Rowland, S. A. (2007). Oral fecal parasites and hygiene of food handlers in Abeokuta. Public Health, 3(121), 455-461.

John, E., Azubuike, C., Collins, Ubbaonu, N., Ebere, C., Kasimir M. Ibe \& Michael, O. O. (2001). Critical control points of complementary food preparation and handling in eastern Nigeria. Bulletin of the World Health Organization, 79(5).

Kimassoum, D., Tidjani, A., Doutoum, A. A., Ameyapoh, Y., Soncy, K., Dossou, K., \& Souza C. (2011). Evaluation of the hygienic quality of the tap water produced by the Togolese Water Company (TdE) for nine districts of the city of Lome (Togo). Microbiol. Hyg. Alim, 23(68), 51-54.

King, L., Awumbila, B., Canacoo, E. A., \& Ofosu-Amah, S. (2000). An assessment of the safety of street foods in the $\mathrm{Ga}$ district of Ghana; implication for the spread of zoonoses. Acta tropica, 76, 39-43. http://dx.doi.org/10.1016/S0001-706X(00)00087-5

Leclerc, H., Schwartzbrod, L., \& Dei-Cas, E. (2002). Microbial agents associated with waterborne diseases. Crit. Rev. Microbiol., 28, 371-409. http://dx.doi.org/10.1080/1040-840291046768

Malhotra, R., Lal, P., Prakash, S. K., Daga, M. K., \& Kishore, J. (2006). Study of hand hygiene and enteroparasite infestation among food handlers working in a medical college of North India. Indian Journal of Pathology and Microbiology, 49(2), 296-301.

Mamontova, L. M., Savilov, E. D., Astaf'ev, V. A., Rakhamanin, I., \& Nedachin, A. E. (2000). Viral pollution of drinking water in industrial towns of eastern Siberia. Gig Sanit., 3, 17-19.

Mellouet, A. G., Perrin, A., Saillard, P., Coulon, P., \& Druet, M. (2009). Food industry, packaging manufacturers. 
Control all food packaging. Benchmarks and tools to control the safety of food, food contact and environmental impact of plastic food packaging. Methodological and technical guide. $47 \mathrm{p}$.

Mosyupe, F. M., \& Van, H. A. (2000). Microbiological hazard identification and exposure assessment of street food vending in Johannesburg, South Africa. Int. J. Food Microbiol., 61, 137-145. http://dx.doi.org/10.1016/S0168-1605(00)00264-6

Motarjemi, Y., \& Kaferstein, F. (1999). Food safety, Hazard Analysis Critical Control Point and the increase in foodborne diseases: a paradox? Food Control., 10, 325-333. http://dx.doi.org/10.1016/S0956-7135(99)00008-0

Muinde, O. K., \& Kuria, E. (2005). Hygienic and sanitary practices of vendors of street foods in Nairobi, Kenya. AJFAND, 5, 1-13.

Nichols, L. G. (2005). Fly transmission of campylobacter. Emerg. Infect. Dis., 11, 361-364. http://dx.doi.org/10.3201/eid1103.040460

Oliveira, A. M., Gonçalves, A. M., Shinohara, N. K. S., \& Stamford, T. L. M. (2003). Manipuladores de Alimentos: Um fator de risco. Higiene Alimentar, 17(114-115), 12-19.

Panza, S. G. A., \& Sponholz, T. K. (2008). Manipulador de alimentos: um fator na transmissão de enteroparasitoses? Higiene Alimentar, 22(158), 42-47.

Petersen, J. H., Breidhal T. (2000). Plasticizers in Total diet samples, baby food and infant formulates. Food Additives and contaminants, 17, 133-141. http://dx.doi.org/10.1080/026520300283487

Pérez-Rodríguez, F., van Asselt, E. D., García-Gimeno, R. M., Zurera, G., \& Zwietering, M. H. (2007). Extracting additional risk managers information from a risk assessment of Listeria monocytogenes in deli meats. Journal of Food Protection, 70, 1137-1152.

Pérez-Rodríguez, F., Castro, R., Posada-Izquierdo, G. D., Valero, A., Carrasco, E., García-Gimeno, R. M., \& Zurera, G. (2010). Evaluation of hygiene practices and microbiological quality of cooked meat products during slicing and handling at retail. Meat Science, 86, 479-485. http://dx.doi.org/10.1016/j.meatsci.2010.05.038

Quittet, C., \& Nelis, H. (1999). HACCP for SMEs and craftsmen. Meat and fish sectors. Agronomic presses Gembloux, 605, 135.

Rozier, J. (1996). Conditioning techniques fishery products: quality assurance and HACCP hygienic. Journal of Microbiology and Food Hygiene, 8 (21), 19-25.

Souza, E. L., Silva, C. A., \& Souza, C. P. (2004). Qualidade Sanitária de Equipamentos,Superfícies, água e mãos de manipuladores de alguns estabelecimentos quecomercializam alimentos na cidade de João Pessoa, PB. Hygiene Alimentar, 18(116), 98-102.

Szalanski, A. L., Owens, C. B., McKay, T., Steelman, C. D. (2004). Detection of Campylobacter and Escherichia coli O157:H7 from filth flies by polymerase Chain reaction. Med Vet. Entomol., 18, 241-246. http://dx.doi.org/10.1111/j.0269-283X.2004.00502.x

Tidjani, A., Doutoum, A. A., Bechir, M., Abderahim, I., Telar, D. Y., Ngabozia, M. J., \& Mornonmbaye, N. (2013). Process quality assurance for control of the diagrams of homemade cheese marketed in chad: case of dairy "AL-KHALILA". Continental J. Food Science and Technology, 7(2), 1-15. doi:10.5707/cjfst.2013.7.2.1.15

Tidjani, A Agassounon Djikpo Tchibozo M, Ouattara MS, Toukourou F, De Souza C. (2008). Determination of aflatoxins in "kilichi" and their ingredients in Chad, Microbiol. Hyg. Alim. 20, 27-34.

Umoh, V. J., \& Odoba, M. B. (1999). Safety and quality evaluation of street foods sold in Zaria, Nigeria. Food Contr, 10, 9-14. http://dx.doi.org/10.1016/S0956-7135(98)00149-2

Vorst, K. L., Todd, E. C. D., \& Ryser, E. T. (2006). Transfer of Listeria monocytogenes during slicing of turkey, bologna, and salami with simulated kitchen knives. Journal of Food Protection, 69(12), 2939-2946-626.

WHO. (2004). Water-related diseases. Water Sanitation and Health. Retrieved from http://www.who.int/water_sanitaion_health/disease/diarrhoea/en.

Wilson, D. M., \& Payne, G. A. (1994). Factors affecting Aspergillus flavus group infection and aflatoxin. Humain health, veterinary and agricultural significance. In D. L. Eaton \& J. D. Groopman (Eds.), Academic press INC, (pp. 309-325), London. 
Yasmeen, G. (2001). Workers in the urban « informal » food sector: innovative organizing strategies. Food. Nutr. Agric., 29, 32-41.

\section{Copyrights}

Copyright for this article is retained by the author(s), with first publication rights granted to the journal.

This is an open-access article distributed under the terms and conditions of the Creative Commons Attribution license (http://creativecommons.org/licenses/by/3.0/). 